\title{
Phenotypic characterization of cassava ethno-varieties in the state of Mato Grosso, Brazil
}

\author{
A.V.Tiago ${ }^{1}$, E.C.M.Pedri ${ }^{1}$, F.S.Rossi ${ }^{2}$, L.L.Santos ${ }^{3}$, J.A.Lima ${ }^{4}$, \\ E.S.Cardoso $^{1}$, A.P.Roveda ${ }^{3}$, E.S.S.Hoogerheide ${ }^{5}$ and A.A.B.Rossi ${ }^{6}$ \\ ${ }^{1}$ Programa de Pós-Graduação em Biodiversidade e Biotecnologia da Rede \\ Bionorte, Universidade do Estado de Mato Grosso Carlos Alberto Reyes \\ Maldonado, Alta Floresta, MT, Brasil \\ ${ }^{2}$ Programa de Pós-Graduação em Biodiversidade e Agroecossistemas \\ Amazônicos, Universidade do Estado de Mato Grosso Carlos Alberto Reyes \\ Maldonado, Alta Floresta, MT, Brasil \\ ${ }^{3}$ Licenciatura e Bacharelado em Ciências Biológicas, Universidade do Estado de \\ Mato Grosso Carlos Alberto Reyes Maldonado, Alta Floresta, MT, Brasil \\ ${ }^{4}$ Programa de Pós-Graduação em Genética e Melhoramento de Plantas, \\ Universidade do Estado de Mato Grosso Carlos Alberto Reyes Maldonado, Alta \\ Floresta, MT, Brasil \\ ${ }^{5}$ Embrapa Agrossilvipastoril, Sinop, MT, Brasil \\ ${ }^{6}$ Universidade do Estado de Mato Grosso Carlos Alberto Reyes Maldonado, \\ Faculdade de Ciências Biológicas e Agrárias, PPGBionorte, PPGBioAgro, \\ PGMP, Laboratório de Genética Vegetal e Biologia Molecular, Centro de \\ Pesquisa e Tecnologia da Amazônia Meridional, Alta Floresta, MT, Brasil
}

Corresponding author: A.A.B. Rossi

E-mail: anabanrossi@unemat.br

Genet. Mol. Res. 19 (2): gmr18538

Received December 05, 2019

Accepted May 31, 2020

Published June 30, 2020

DOI http://dx.doi.org/10.4238/gmr18538

\begin{abstract}
Brazil is the fourth largest producer of cassava in the world. In the state of Mato Grosso more than $90 \%$ of family farmers grow cassava; therefore, studies that evaluate the genetic resources of this species present in the fields of these farmers can be considered essential. The objective of this study was to evaluate the genetic variability among ethnovarieties of cassava grown in five regions of the state of Mato Grosso, at a phenotypic level using morphoagronomic and molecular characteristics. Forty-five ethnovarieties of cassava were evaluated using 45 morphoagronomic descriptors, 36 qualitative descriptors and nine quantitative descriptors, in addition to 15 microsatellite loci. The data were analyzed with the help of the Past and
\end{abstract}


Genes programs. The descriptors of qualitative nature revealed the existence of morphological divergence, with $97.35 \%$ polymorphism and the formation of five genetic groups using the UPGMA method. Forty-four ethno-varieties had more than one desirable root characteristic from an agronomic point of view. Among all the varieties, the Amarela I ethno-variety had the most of these characteristics. With the quantitative variables obtained using the UPGMA method, it was possible to form seven distinct groups, which revealed the Branca Comum and Paraguaia ethno-varieties to be the most dissimilar. The characteristic that most contributed to the distinction of the groups was that of root length (30\%). The 15 microsatellite loci amplified 109 alleles, and mean heterozygosity observed was higher than the expected heterozygosity. The UPGMA grouping revealed the formation of four distinct groups, and it was possible to verify duplicity of the Mandioca Batatinha and Pramuquem ethnovarities. By using joint analysis of the data, five genetic groups were observed, without duplicity of material; groups III, IV and $\mathrm{V}$ were isolated individuals. Between qualitative and quantitative variables, there was a significant correlation of $31 \%$ and between qualitative and molecular data the correlation was $12.4 \%$. The collection of ethnovarieties grown in the fields of family farmers in the state of Mato Grosso present genetic divergence at the phenotypic level, based on morphoagronomic and molecular characteristics, and these ethno-varieties have characteristics of interest for genetic improvement and improved marketability.

Key words: Manihot esculenta; Genetic resources; Joint analysis

\section{INTRODUCTION}

Cassava (Manihot esculenta) is characterized by its wide genetic diversity; there are many local varieties that are capable of adapting to different regions (Nick et al., 2010). Mainly cultivated by family farmers in over 100 tropical and subtropical countries, it is a major source of energy for millions of people because its roots are rich in carbohydrates (FAO, 2013). The roots can be converted into ethanol, which serves as a renewable energy source (Avijala, 2013).

The peculiar characteristics found in cassava enable it to be grown in virtually all Brazilian regions, and its cultivation occurs mainly in the north, northeast, southeast, south and midwest regions of the country (EMBRAPA, 2017; SEAB, 2017). Family farming alone accounts for $76 \%$ of the national production of cassava (Souza et al., 2012). In the state of Mato Grosso, more than $90 \%$ of family farmers cultivate cassava, as well as producing fruit and milk (EMBRAPA, 2014).

The genetic diversity of cassava ethno-varieties in Brazil provides a broad genetic basis for breeding programs (Fukuda et al., 2005). The genetic diversity present in the species is related to the large number of ethno-varieties cultivated by small, family farmers and presents specific characteristics that are not normally found in improved materials (Alves-Pereira et al., 2011).

Several tools are used to estimate genetic divergence in studies on cassava, such as the use of qualitative and quantitative phenotypic characters, as well as molecular markers. Morphological descriptors are considered the "business card" in cassava varieties. In 
addition to influencing the farmers' choice regarding varieties, they are also considered indicators of variability among ethno-varieties (Siqueira, 2008). Among the characteristics that can be used for the evaluation of varieties of cassava, the characteristics most influenced by the environment are the quantitative descriptors which, despite being controlled by many genes, have a very small individual effect. Most characteristics of economic interest are quantitative, such as yield, vegetative cycle and plant height. The qualitative ones are those that have distinct phenotypic classes, and their expression is minimally affected by the environment, and these characteristics are usually controlled by only a few genes. Therefore, they have a high correlation between genotype and phenotype and, consequently, rapid responses to selection, and are easily fixed (Vieira et al., 2008a; Borém and Caixeta, 2016).

On the other hand, molecular markers are frequently used in studies on diversity, since they do not suffer environmental influences. This information is used to identify individuals, allow analysis of materials of interest, and associate variability with phenotypic characteristics (Faraldo et al., 2000; Siqueira, 2008).

Among the molecular markers available, the microsatellites (SSR - Simple sequence Repeats) are noteworthy. The microsatellite technique reveals polymorphism in the locus due to size differences in the allele, which provides a high degree of information, quick and easy genotyping, and distribution throughout the genome as well as its codominant nature (Ferreira and Grattaplagia, 1998; Carrasco, 2012).

Other studies have also been performed using qualitative, quantitative and molecular phenotypic characterization information, such as those published by Vieira et al. (2008a), Mezette (2013), Vieira et al. (2013), Mtunguja et al. (2015), and Zago et al. (2017).

Taking into account the economic and dietary importance of cassava for family farming in all Brazilian regions, and in particular in the state of Mato Grosso, as well as the large number of ethno-varieties cultivated in the fields of the family farmers, we aimed to evaluate the genetic variability among these cassava samples grown in five regions of the state of Mato Grosso, Brazil, at the phenotypic level based on morphoagronomic and molecular characters.

\section{MATERIAL AND METHODS}

\section{Study area}

We evaluated 45 cassava ethno-varieties which were obtained in the municipalities of Alta Floresta (27), Apiacás (10), Jangada (4), Cuiabá (3) and Poconé (1) (Figure 1 and Table 1). In each locality only cassava samples with different names were collected, and the identification of ethno-varieties was based on the knowledge of the farmers, or rather, how the farmers identified the variety, hence the term "ethno-varieties" (Tiago et al., 2019).

The experimental plantation was started in January 2017, in Alta Floresta, MT, on the São Paulo smallholding, which is located in the Nova Esperança Community, on the Segunda Oeste highway, MT 208 (Figure 1).

The municipality of Alta Floresta $\left(9^{\circ} 57^{\prime} 00.8^{\prime \prime} \mathrm{S}, 56^{\circ} 05^{\prime} 44.4^{\prime \prime} \mathrm{W}\right)$ has an Am type climate, with two well-defined seasons, rainy summer and dry winter, characterized by 
annual average temperatures above $24^{\circ} \mathrm{C}$ and rainfall above 2,500 $\mathrm{mm}$ (Alvares et al., 2013), and its soil is characterized as dystrophic red-yellow latosol (Embrapa, 2013).

The experiment was conducted without repetition, with each plot consisting of one line of approximately 10 plants of each ethno-variety (this number varied according to the availability of propagative material). Three plants were evaluated per plot. The spacing between lines and between plants was $1.5 \mathrm{~m}$. The $15-20 \mathrm{~cm}$ lengths of stalk were planted horizontally at a depth of $10 \mathrm{~cm}$.
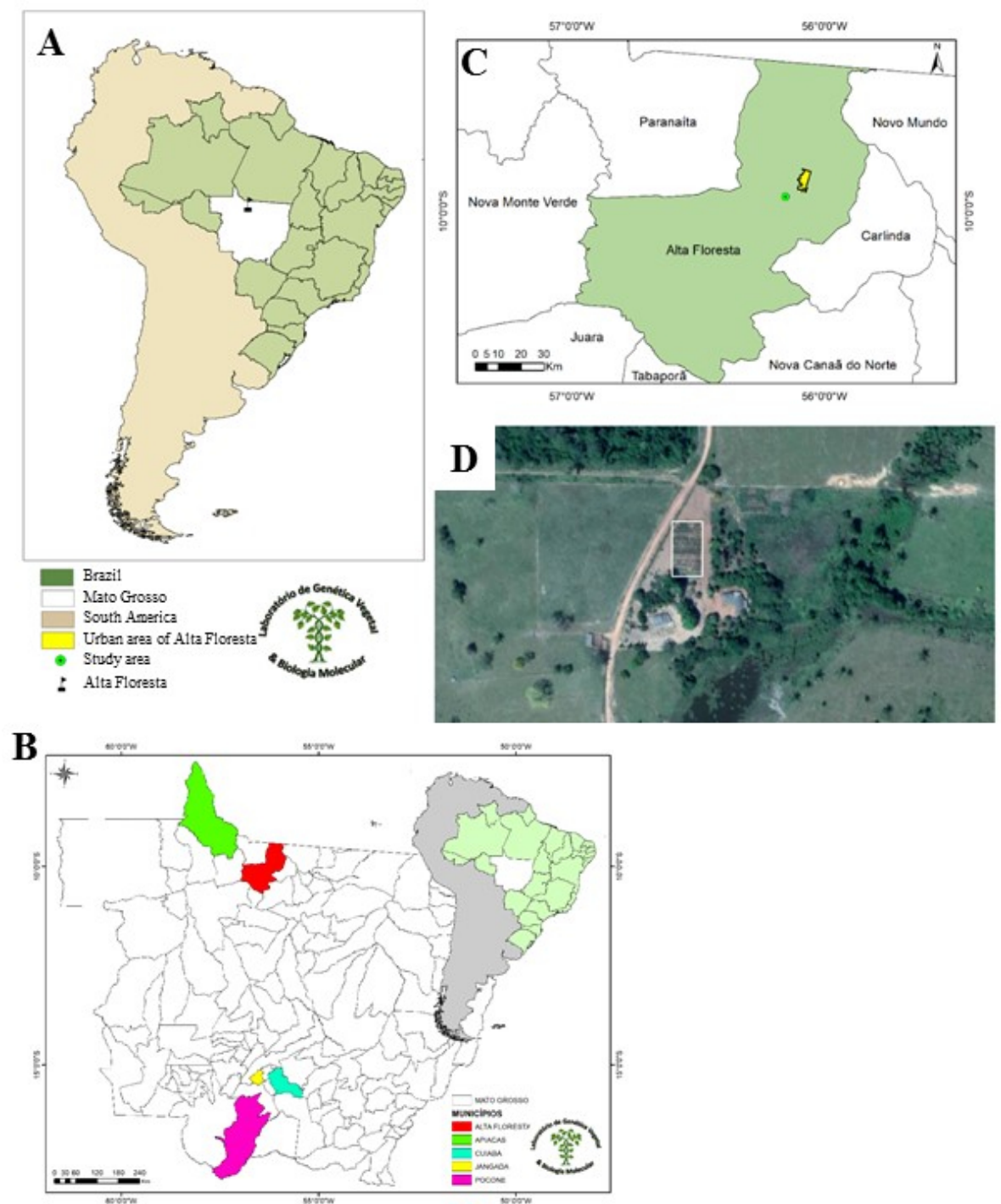

Figure 1. Collection area and location of the cassava planting experiment. A) Location of the state of Mato Grosso (MT) in South America; B) Location of the municipalities where material was obtained in the state of MT; C and D) Location of the municipality of Alta Floresta and location of the experimental field. 
Table 1. Identification of 45 cassava ethno-varieties collected in the state of Mato Grosso.

\begin{tabular}{|c|c|c|c|c|c|}
\hline Code & Popular name & $\begin{array}{l}\text { Collection area } \\
\text { (MT) }\end{array}$ & Code & Popular name & $\begin{array}{l}\text { Collection area } \\
\text { (MT) }\end{array}$ \\
\hline$\overline{\mathrm{AF} 01}$ & Cacau Roxa & Alta Floresta & AF25 & Mandioca Batatinha & Alta Floresta \\
\hline $\mathrm{AF} 02$ & Cacau Arara & Alta Floresta & AF26 & Pramuquem & Alta Floresta \\
\hline $\mathrm{AF} 03$ & Mandioca Cenoura & Alta Floresta & AF39 & Antena & Alta Floresta \\
\hline AF04 & Cacau Branca & Alta Floresta & AF40 & Paraguaia & Alta Floresta \\
\hline AF05 & Cacau Pinheiro & Alta Floresta & AP27 & Mandioca de São Paulo & Apiacás \\
\hline AF06 & Mandioca Pão & Alta Floresta & AP28 & Mandioca Manteiguinha & Apiacás \\
\hline AF07 & Vassourinha & Alta Floresta & AP29 & Mandioca Liberata & Apiacás \\
\hline AF08 & Branca Comum & Alta Floresta & AP30 & Mandioca Peixe & Apiacás \\
\hline AF09 & Mandioca de Ano & Alta Floresta & AP32 & Cacauzinha & Apiacás \\
\hline AF10 & Mandioca Eucalipta & Alta Floresta & AP33 & $\begin{array}{l}\text { Mandioca de Fritar sem cozinhar } \\
\text { III }\end{array}$ & Apiacás \\
\hline $\mathrm{AF} 11 \mathrm{~A}$ & Branca do Baiano & Alta Floresta & AP34 & Boliviana & Apiacás \\
\hline $\mathrm{AF} 11 \mathrm{~B}$ & Branca do Baiano & Alta Floresta & AP36 & Branca s/nome & Apiacás \\
\hline AF12 & Cacau Amarela & Alta Floresta & AP37 & Manteiga (pão) & Apiacás \\
\hline AF13 & Amarela I & Alta Floresta & AP38 & Amarela de Minas & Apiacás \\
\hline AF14 & Amarela II & Alta Floresta & JM02 & Macaxeira & Jangada \\
\hline AF16 & Mandioca de Fritar sem Cozinhar & Alta Floresta & JM03 & Broto Branco & Jangada \\
\hline AF17 & Amarela III & Alta Floresta & JM07 & Sem Nome & Jangada \\
\hline AF18 & Amarela da Bahia & Alta Floresta & JM38 & Liberata & Jangada \\
\hline AF19 & Mandioca da Folha Roxa & Alta Floresta & $\mathrm{RC} 27$ & Osso & Cuiabá \\
\hline AF20 & Mandioca 3 meses & Alta Floresta & $\mathrm{RC} 37$ & Amarela & Cuiabá \\
\hline $\mathrm{AF} 21$ & Cacau Copinha & Alta Floresta & $\mathrm{RC} 38$ & Brancona & Cuiabá \\
\hline $\mathrm{AF} 22$ & Mandioca fritar sem cozinhar II & Alta Floresta & SB14 & Carneiro & Poconé \\
\hline AF23 & Amarela Folha Fina & Alta Floresta & ------ & --------- & ------ \\
\hline
\end{tabular}

\section{Morpho-agronomic and molecular characterization}

For the morpho-agronomic characterization, 45 descriptors were used, as described by Fukuda and Guevara (1998). Figure 2 illustrates the evaluation of some of the morphoagronomic descriptors. In total, there were 36 qualitative descriptors presented (Table 2). Of these, 26 were evaluated eight months after planting, and the remaining 10 were evaluated 12 months after planting.

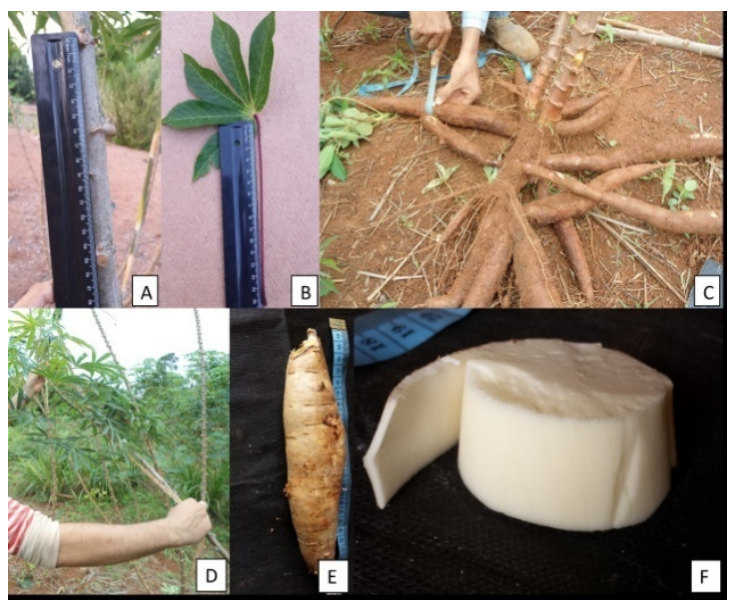

Figure 2. Illustration of the evaluation of some morpho-agronomic descriptors used in the analysis of the 45 cassava ethno-varieties. A) Phyllotaxis Length; B) Petiole length; C) Root position and diameter; D) Plant height; E) Length and external color of root and F) Root pulp color. 
Nine quantitative variables were measured: mean root length $(\mathrm{cm})$; mean root diameter $(\mathrm{cm})$; number of roots per plant; leaf lobe length (five leaves of each plant $(\mathrm{cm})$; leaf lobe width (five leaves of each plant $(\mathrm{cm})$; center lobe width $\mathrm{x}$ length ratio $(\mathrm{cm})$; petiole length $(\mathrm{cm})$; plant height $(\mathrm{m})$ height of first branch $(\mathrm{cm})$. Three plants were used in all the analyses.

Table 2. Qualitative characteristics used in the evaluation of 45 cassava ethno-varieties, based on the descriptors of Fukuda and Guevara (1998).

\begin{tabular}{|c|c|c|}
\hline No. & $\begin{array}{l}\text { Characteristics } \\
\text { Characteristics evaluated at eight months }\end{array}$ & Phenotypic classes \\
\hline 1 & Apical Leaf Color & (1) light green, (2) dark green, (3) purplish green, (4) purple \\
\hline 2 & Pubescence in apical leaves & (1) present; (0) absent \\
\hline 3 & Leaf Retention & (1) $100 \%$; (2) $75 \%$; (3) $50 \%$; (4) $25 \%$ \\
\hline 4 & Center lobe shape & $\begin{array}{l}\text { (1) ovoid; (2) elliptical-lanceolate; (3) obovate-lanceolate; (4) } \\
\text { oblong-lanceolate; (5) lanceolate; (6) straight or linear; (7) pendurate } \\
\text { (8) linear-pyramidal; (9) linear-pandurate; (10) linear-hostatilobada }\end{array}$ \\
\hline 5 & Leaf color when fully-grown & (1) light green, (2) dark green, (3) purplish green \\
\hline 6 & Number of lobes on each leaf & (1) three; (2) five; (3) seven; (4) nine; (5) eleven (6) thirteen \\
\hline 7 & Petiole color & $\begin{array}{l}\text { (1) yellowish green; (2) green; (3) reddish green; (4) greenish red; (5) } \\
\text { red; (6) purple }\end{array}$ \\
\hline 8 & $\begin{array}{l}\text { Rib color (observed at the bottom of the central lobe ( } \\
\text { of the leaf) }\end{array}$ & $\begin{array}{l}\text { (1) green; (2) less than half was reddish green; (3) more than half was } \\
\text { reddish green; (4) all red }\end{array}$ \\
\hline 9 & Petiole Position & (1) tilted up; (2) horizontal; (3) tilted down; (4) irregular \\
\hline 10 & Prominence of leaf scars & (0) no prominence (1) prominence \\
\hline 11 & External color of stem & $\begin{array}{l}\text { (1) orange; (2) yellowish green; (3) golden; (4) light brown; (5) } \\
\text { silver; (6) grey; ( } 7 \text { ) dark brown; (8) green }\end{array}$ \\
\hline 12 & Stem cortex color & (1) yellow; (2) light green; (3) dark green \\
\hline 13 & Stem epidermis color & (1) cream; (2) light brown; (3) dark brown; (4) orange \\
\hline 14 & Phyllotaxis Length & (1) short $<8 \mathrm{~cm}$; (2) medium $8-15 \mathrm{~cm}$; (3) long $>15 \mathrm{~cm}$ \\
\hline 15 & Stem growth style & (1) straight; (2) zig-zag \\
\hline 16 & Color of terminal branches in adult plants & (1) green; (2) purplish green; (3) purple \\
\hline 17 & Length of stipules & (3) short (5) long \\
\hline 18 & Margin of stipules & (1) lacinated (2) whole \\
\hline 19 & Fruits & (0) absent; (1) present \\
\hline 20 & Seeds & (0) absent; (1) present \\
\hline 21 & Branching levels & $\begin{array}{l}\text { (0) no branches; (1) one level; (2) two levels; (3) three levels; (4) four } \\
\text { levels; (5) five levels }\end{array}$ \\
\hline 22 & Branching patterns & $\begin{array}{l}\text { (1) no branches; (2) erect; (3) dichotomous; (4) trichotomous; (5) } \\
\text { tetracotomic }\end{array}$ \\
\hline 23 & Plant type & (1) Compact; (2) open; (3) umbrella; (4) cylindrical \\
\hline 24 & Florescence & (0) absent; (1) present \\
\hline 25 & Sinuosity of leaf lobe & (3) smooth; (7) sinuous \\
\hline 26 & Damage by pests and diseases & $\begin{array}{l}\text { (1) none; (2) } 25 \% \text {; (3) } 50 \% \text {; (4) } 75 \% \text {; (5) } 100 \% \\
\text { Characteristics evaluated at } 12 \text { months }\end{array}$ \\
\hline 27 & Presence of peduncle in the roots & (0) sessile; (1) pedunculated; (2) mixed (both) \\
\hline 28 & Position of roots & (1) vertical tendency; (2) horizontal tendency; (3) irregular \\
\hline 29 & External color of roots & (1) white or cream; (2) yellow; (3) light brown; (4) dark brown \\
\hline 30 & Root epidermis texture & (3) smooth; (7) rough \\
\hline 31 & Root constrictions & (1) few or none; (2) average; (3) many \\
\hline 32 & Root format & (1) conical; (2) conical - cylindrical; (3) cylindrical; (4) irregular \\
\hline 33 & Root cortex color & (1) white or cream; (2) yellow; (3) pinkish; (4) purple \\
\hline 34 & Root pulp color & (1) white; (2) cream; (3) yellow; (4) pink \\
\hline 35 & Ease of root skin removal & (1) easy; (4) difficult \\
\hline 36 & Ease of root cortex removal & (3) easy; (7) difficult \\
\hline
\end{tabular}

For molecular analyses, DNA was extracted according to the Doyle and Doyle (1990) protocol based on CTAB (Cetyl Trimethyl Ammonium Bromide) method, with 
modifications: STE buffer to macerate leaves instead of liquid nitrogen, increase in polyvinylpyrrolidone (PVP) concentration from $1 \%$ to $2 \%$ and $\beta$-mercaptoethanol from 0.2 to $2 \%$ in the extraction buffer, and incubation time at $65^{\circ} \mathrm{C}$ reduced from $60 \mathrm{~min}$. to $30 \mathrm{~min}$. To visualize the result of DNA extraction, the individuals were applied to $1 \%$ agarose gel which was stained with GelRed (Biotium, Hayward, USA). Then, the samples were quantified based on the absorbance at $260 \mathrm{~nm}$, and the purity analysis was done based on the absorbance ratio at 260 and $280 \mathrm{~nm}$ using a Nanodrop-2000 spectrophotometer (Thermo Fisher Scientific). After quantification, DNA concentrations were standardized to 100 $\mathrm{ng} / \mu \mathrm{L}$.

For amplification of the material, 15 microsatellite loci (SSR) were selected, as described and used by Chavarriaga-Aguirre et al. (1998) and Mba et al. (2001). The SSRs were labeled with 6-FAM fluorochrome (blue) and HEX (green) as described in Table 3.

Table 3. SSR primers used in the molecular characterization of 45 cassava ethno-varieties collected in the state of Mato Grosso. Annealing temperature $=53^{\circ} \mathrm{C}$.

\begin{tabular}{llll}
\hline Duplex & Loci & Fluorochrome & (bp) \\
\hline 1 & SSRY-21** & FAM & $172-212$ \\
& SSRY-28** & HEX & $160-214$ \\
2 & SSRY-27** & FAM & $245-297$ \\
& SSRY-35** & HEX & $174-310$ \\
3 & SSRY-8** & FAM & $268-320$ \\
& GAGG-5* & HEX & $108-150$ \\
4 & GA-12* & FAM & $119-180$ \\
& GA-21* & HEX & $104-146$ \\
5 & GA-131* & FAM & $75-141$ \\
& SSRY-43** & HEX & $229-275$ \\
& SSRY-47* & FAM & $216-280$ \\
7 & SSRY-126* & HEX & $225-297$ \\
8 & GA-136* & FAM & $145-185$ \\
$*$ GA-140* & HEX & $154-192$ \\
& SSRY-40* & HEX & $211-269$
\end{tabular}

Amplification reactions were conducted in a duplex system (Table 3), with a final volume of $10 \mu \mathrm{L}$, containing $1 \mu \mathrm{L}$ Buffer [0.05\% (w/v) bromphenol blue, $40 \%(\mathrm{w} / \mathrm{v})$ sucrose, $0,1 \mathrm{M}$ EDTA $\mathrm{pH}$ 8.0, 0.5\% (w/v) sodium lauryl sulfate (SDS)]; $0.8 \mu \mathrm{L}$ of dNTPs $(2.5 \mathrm{mM}) ; 0.13 \mu \mathrm{L}$ and $0.5 \mu \mathrm{L}$ for each primer (forward and reverse $(20 \mathrm{mM})$, respectively); $0.2 \mu \mathrm{L}$ of Taq DNA Polymerase ( $5 \mathrm{U}) ; 0.25 \mu \mathrm{L}$ of the HEX and FAM labeling solution (2 $\mathrm{mM}) ; 2 \mu \mathrm{L}$ DNA, and then the volume was topped up with Milli-Q ultrapure water.

The amplifications were performed in a T100 "Thermal Cycler" Bio-RAD thermal cycler under the following conditions: initial denaturation at $94^{\circ} \mathrm{C}$ for $5 \mathrm{~min}$; 30 cycles followed by denaturation at $94^{\circ} \mathrm{C}$ for $30 \mathrm{~s}$; an annealing temperature of $45^{\circ} \mathrm{C}$ for $45 \mathrm{~s}$ and $72^{\circ} \mathrm{C}$ for $45 \mathrm{~s}$ and eight cycles at $94^{\circ} \mathrm{C}$ for $30 \mathrm{~s}, 53^{\circ} \mathrm{C}$ for $45 \mathrm{~s}, 72^{\circ} \mathrm{C}$ for $45 \mathrm{~s}$, and a final extension of $72^{\circ} \mathrm{C}$ for $10 \mathrm{~min}$. Microsatellite genotyping was performed in capillary electrophoresis in the Automatic DNA Analyzer ABI 3130XL Genetic Analyzer (Applied Biosystems, Foster City, California, USA). Subsequently, the size of the amplified fragments was determined by comparison with a DNA of known size Rox 500 (APPLIED BIOSYSTEMS) using the program GeneMarker® v. 2. 6.3 (Softgenetics). 


\section{Statistical analysis}

Qualitative variables were analyzed as quantitative binary multi-categories. This methodology is based on Euclidean distance (D) and has the advantage that it can be applied to cases where the evaluated accessions do not necessarily present a single category for each multi-categorical characteristic, in which the variables are represented by values that represent the amount of a particular class when evaluating the sample of individuals from a given accession (Cruz and Regazzi, 2001; Cruz, 2006). That is, each characteristic was represented by its classes and the number of plants evaluated was indicated in each class. The dissimilarity index used is given by:

$$
d_{i i^{\prime}}=\sum_{j=1}^{v} \sum_{k=1}^{n_{j}} \frac{\delta_{k j}^{2}}{n_{j}^{*}}
$$

in which $n_{j}^{*}$ is the number of categories between accession pairs for a given variable, where there was no absence of values observed in both accessions simultaneously.

$\delta_{k j}=Y_{I k j}-Y_{I^{\prime} k j}$ : deviation of the observed quantity of category $\mathrm{k}$, of the $\mathrm{j}^{\text {th }}$ variable, from the pair of accessions $i$ and $i$ '.

Subsequently, the percentage of polymorphism for qualitative morphological descriptors determined by the presence and absence of the characteristic found in the evaluated materials was estimated.

The qualitative characteristics of agronomic interest in relation to the root (pulp color being yellow; little or no constriction; root cortex color being white or cream; easy removal of cortex and external root color being white), were grouped by the method UPGMA (Unweighted Pair-Group Method Using an Arithmetic Average) by using the program PAST.

For quantitative data, the file of means, which was converted to Euclidean distance (D), was used, then the relative importance of the descriptors was determined as proposed by Singh (1981).

The genetic relationships between cassava ethno-varieties from molecular data (SSR) were evaluated using the dissimilarity matrix, constructed using the Jaccard dissimilarity index complement for co-dominant and multi-allelic data. From this transformation we obtained the number of alleles per locus (n), expected heterozygosity $\left(H_{e}\right)$ and observed heterozygosity $\left(H_{o}\right)$, polymorphic information content (PIC) and inbreeding coefficient $(f)$ (Cruz et al., 2011).

The genetic distance for the joint analysis of quantitative, qualitative and molecular variables was performed based on the algorithm by Gower (1971), given by:

$$
S_{i j k}=\frac{\sum_{K=1}^{p} W_{i j k} \cdot s_{i j k}}{\sum_{K=1}^{P} W_{i j k}}
$$

in which: $\mathrm{K}$ is the number of variables $(\mathrm{k}=1,2, \ldots ; \mathrm{p}=$ total number of characteristics evaluated); $\mathrm{i}$ and $\mathrm{j}=$ any two individuals; $W_{i j k}$ is a weight given to the $\mathrm{ijk}$ comparison, assigning a value of 1 for valid comparisons and a value of 0 for invalid comparisons (when the value of the variable is absent in one or both individuals); $S_{i j k}=$ is the contribution of variable $k$ to the similarity between individuals $i$ and $j$, with values 
between 0 and 1 . For a nominal variable, if the value of variable $\mathrm{k}$ is the same for both individuals, $\mathrm{i}$ and $\mathrm{j}$, then $S_{i j k}=1$, otherwise, it is equal to 0 ; for a continuous variable $S_{i j k}=$ $1-\left|X_{i k}-X_{j k}\right| / R_{k}$ in which $X_{i k}$ and $X_{j k}$ are the values of variable $\mathrm{k}$ for individuals i and $\mathrm{j}$, respectively, and $R_{k}$ is the amplitude of variation of variable $\mathrm{k}$ in the sample. The division by $R_{k}$ eliminates differences between scales of variables, producing a value within the range $[0,1]$ and equal weights.

The hierarchical groupings of the analyses (qualitative, quantitative, molecular and joint analysis) from the genetic distance matrices were obtained by the UPGMA method. (Unweighted Pair-Group Method Using an Arithmetic Average). The validation of the clusters was determined by the cophenetic correlation coefficient (CCC) according to Sokal and Rohlf (1962). To estimate the significance of the correlation (association) between the dissimilarity matrices obtained in the qualitative, quantitative and molecular character groups, the Mantel matrix comparison test (Z-test) was used, with 5,000 permutations (Mantel, 1967). All analyses were performed using the GENES program (Cruz, 2013).

\section{RESULTS}

\section{Qualitative characterization}

The 36 qualitative morphological descriptors evaluated for the 45 cassava ethnovarieties presented $97.35 \%$ polymorphism, which reveals morphological divergence and efficiency of these estimates in the dissimilarity analysis between the evaluated samples.

Other studies have demonstrated the importance of morphological descriptors, such as those of Vieira et al. (2008a); they evaluated genetic divergence among sugary and nonsugary cassava accessions and observed that of the 33 qualitative characters, 22 presented variability among the accessions. Vieira et al. (2013), while carrying out phenotypic characterization of accessions of cassava for industrial use, based on 33 qualitative characters, observed that 26 showed polymorphism, revealing the existence of wide morphological divergence between accessions. Mtunguja et al. (2015) evaluated the genetic diversity of 52 cassava varieties in farmers' fields with 24 morphological descriptors, and found a total of 82 polymorphic markers, indicating variability among the evaluated varieties.

Of the qualitative descriptors used in our study, three did not reveal variability among cassava ethno-varieties, and all ethno-varieties showed pubescence in apical leaves, upright stem growth habit and horizontally positioned roots, as shown in Figure 3.

By analyzing the qualitative variables by the UPGMA method, five genetic groups were formed, as shown in Figure 4. The GI group was constituted of $84 \%$ individuals, allocating ethno-varieties of Alta Floresta, Cuiabá, Jangada and Apiacás.

The second and fifth groups (GII and GV) were represented by only one individual, AF17 and AF40, respectively, called Mandioca Amarela III e Paraguaia, both from the municipality of Alta Floresta (Table 1), (Figure 5 and 6), and were considered the most divergent groups in relation to the others.

The GIII group was represented by two ethno-varieties (RC38= Amarela and RC37= Brancona), and GIV by three ethno-varieties (AF25 = Mandioca Batatinha; AF39= Antena and RC27= Osso), which came from the municipalities of Cuiabá and Alta Floresta (Table 1). 
Note that groups GI and GIV allocated individuals regardless of their origin, which is indicative that materials from different geographical regions share similar characteristics for qualitative morphological descriptors.

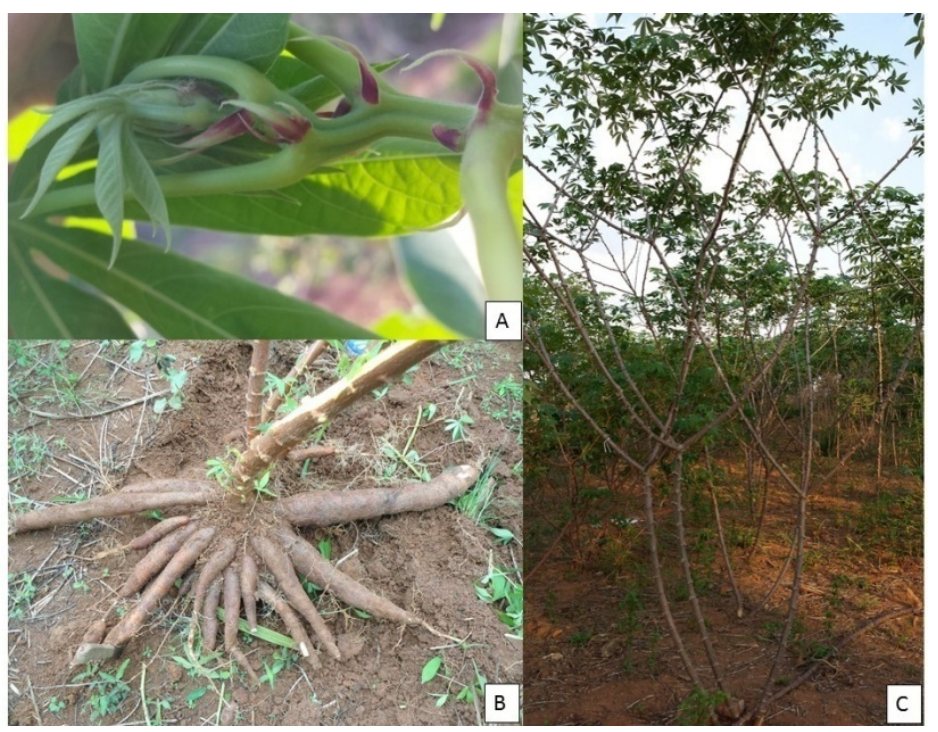

Figure 3. Non-divergent characteristics among cassava ethno-varieties: A) Pubescence in apical leaves; B) Roots in a horizontal position and C) Upright stem growth pattern.

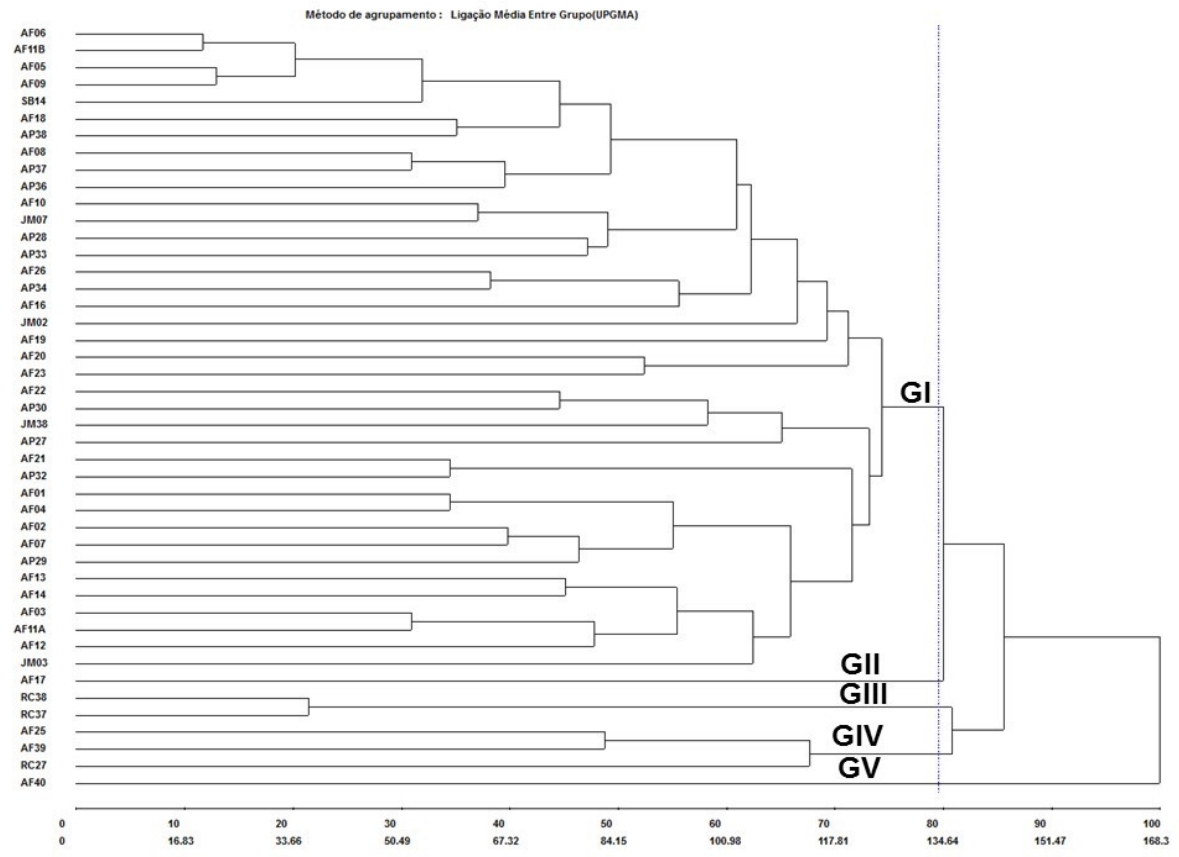

Figure 4. UPGMA Dendrogram obtained via 45 qualitative morphological characteristics based on Euclidean distance in 45 cassava ethno-varieties collected in the state of Mato Grosso. Data obtained using the GENES software (CRUZ, 2013). Cutoff point at $79.55 \%$ and cophenetic correlation coefficient (CCC) $72.53 \%$. 


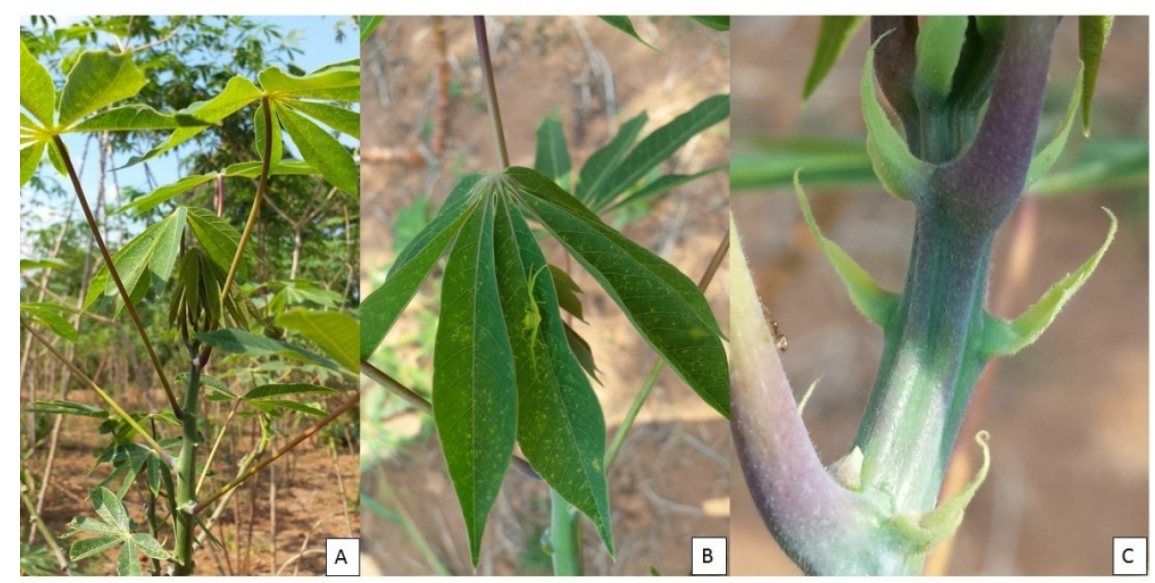

Figure 5. Phenotypic characteristics presented by cassava ethno-variety AF17 (Amarela III), that most contributed to its isolation in the UPGMA cluster. A) Apical leaf color (purplish green) and petiole color (greenish red); B) Central leaf vein color (more than half was reddish green) central lobe shape (obovatelanceolate) and C) Margin of stipules (whole).

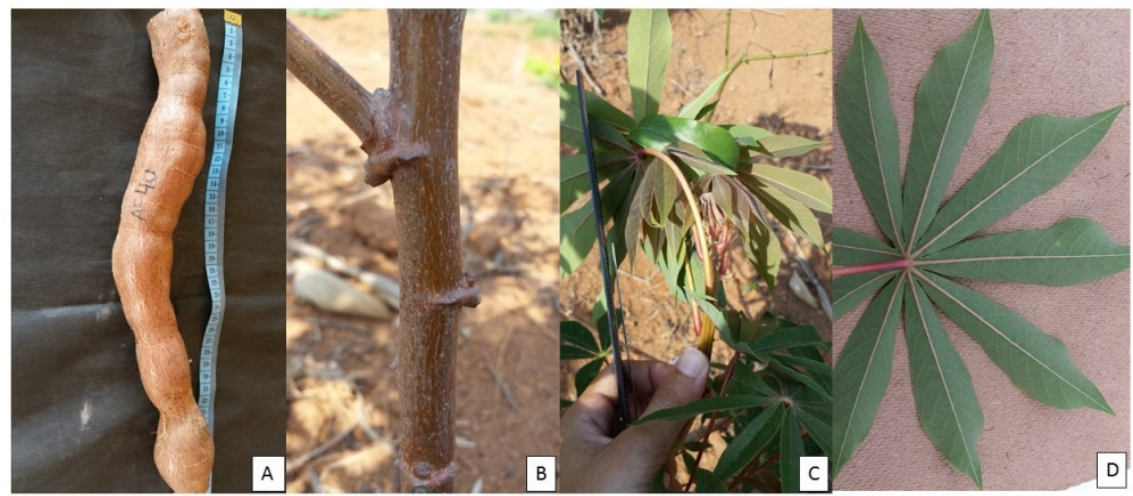

Figure 6. Phenotypic characteristics that most contributed to the differentiation of cassava ethno-variety AF40 (Paraguaia) in relation to the other ethno-varieties. A) Root constrictions (many) and root shape (irregular); B) Stem external color (orange); C) Apical leaf color (purple), leaf retention $(0,25 \%)$ and D) Color of central leaf vein (less than half was reddish green).

According to Silva et al. (2002), Gomes, (2007) and Vieira et al. (2008b), from the point of view of genetic improvement, cassava that has a yellow root pulp color, little or no root constriction, white root cortex color, easy removal of the root cortex, and white external root color can be useful as breeding stock since these are desirable characteristics for the root from an agronomic point of view.

Of the 45 cassava ethno-varieties, only one did not stand out for having the desirable agronomic traits for the root, so only 44 ethno-varieties were evaluated.

Based on the aforementioned criteria, it is possible to observe in our study that $11.12 \%$ of the studied samples had yellow-colored pulp; $55.55 \%$ of roots had little or no constriction; $60 \%$ had white or cream root cortex color; $77.78 \%$ had easy cortex removal and $11.12 \%$ had white external root color, as shown in Figures 7 and 8. 


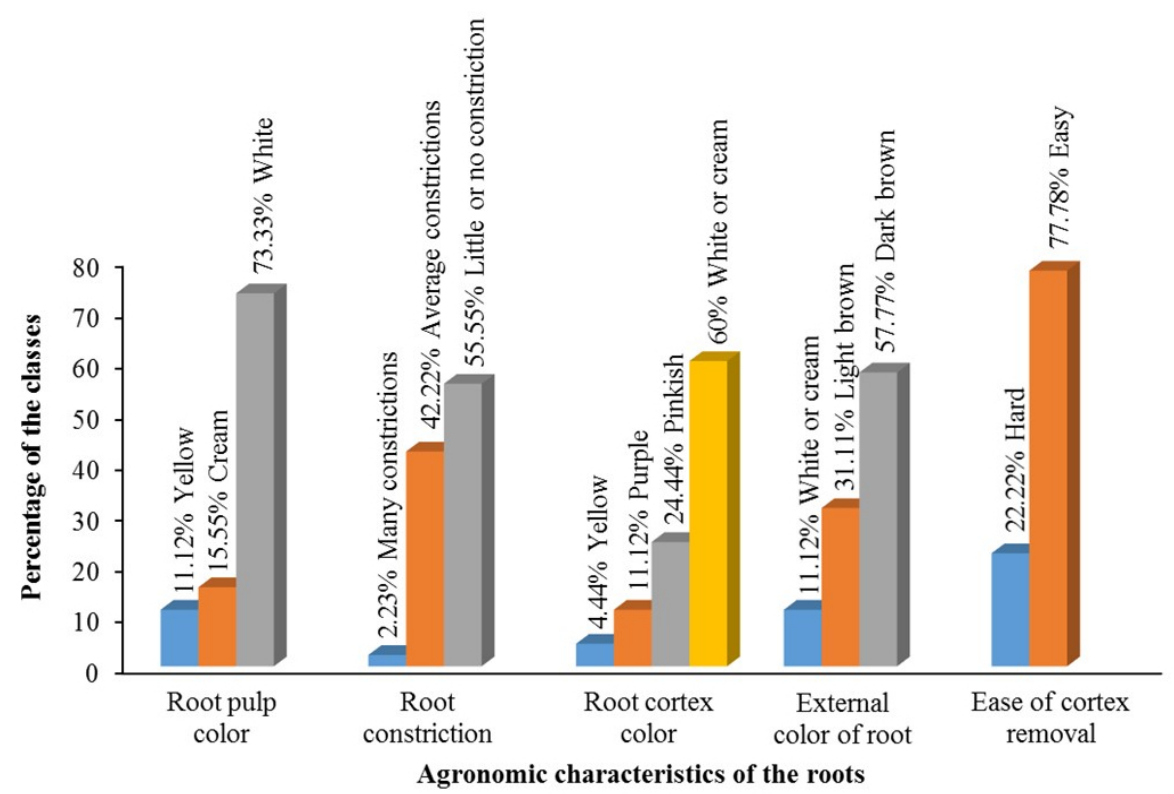

Figure 7. Qualitative characteristics found among 44 cassava ethno-varieties in relation to root.

According to Figure 8, which represents the UPGMA grouping in relation to the five qualitative characteristics for the root, we can observe that the roots with yellow flesh color (PRA) were only present among the ethno-varieties AF16 (Mandioca de Fritar sem Cozinhar); AF13 (Amarela I); AF03 (Mandioca Cenoura); AF14 (Amarela II) and AF19 (Mandioca da Folha Roxa), both belong to the municipality of Alta Floresta (Figure 8).

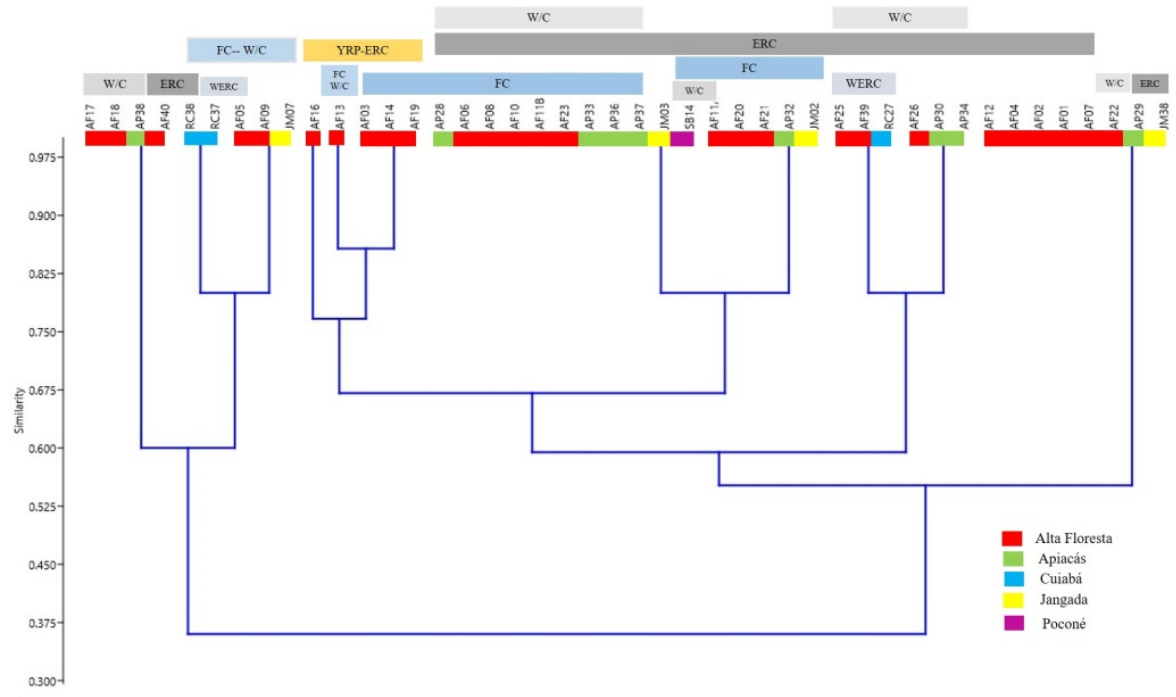

Figure 8. Attributes of agronomic interest presented by some cassava ethno-varieties based on UPGMA clustering via five qualitative root traits. Root cortex color: white or cream (RCC: W/C); Easy removal of cortex (ERC); few or no constrictions (FC); Yellow root pulp (YRP); white external root color (WERC). 
It is noteworthy that the color of the root pulp is one of the determining factors in its value. The color yellow is desirable in the commercialization of cassava, and is also related to its nutritional quality, since it indicates richness in carotenoids that are precursors of vitamin A, which is important in the diet of humans and animals (Iglesias et al., 1997; Barbosa et al., 2007).

Among the 44 ethno-varieties, $70.45 \%$ (31) present more than one characteristic of these five and stand out as being of agronomic interest in relation to root, and $29.55 \%$ (13) show only one desirable characteristic. Among the characteristics of commercial importance, the ethno-variety of AF13 (Amarela I) is the one that congregates the majority of these characteristics - four characteristics of the five which we have highlighted, as shown in Figure 8. This indicates that this ethno-variety may serve as a progenitor in breeding programs, due to its favorable set of alleles.

\section{Quantitative Characterization}

The estimated genetic distances between the 45 ethno-varieties ranged from 1.870 to 0.154, with the shortest distance observed between AF10 and AF16 (Mandioca Eucalipta and Mandioca de Fritar sem Cozinhar). While the largest genetic distance was found between AF08 and AF40, called Branca Comum and Paraguaia, both of which were acquired in Alta Floresta.

Considering the nine descriptors obtained by quantitative variables, the analysis of genetic divergence by the UPGMA method had a cut off point of $83.90 \%$, which made it possible to form seven distinct groups (GI, GII, GIII, GIV, GV, GVI and GVII), the first group (GI) and the fourth group (GIV) were the most numerously populated, and were composed of $67 \%$ ethno-varieties and $13 \%$ ethno-varieties, respectively. The groups GII, GIII and GVII were constituted by two and three ethno-varieties, respectively. The GV and GVI groups allocated only one sample each, identified as Sem Nome (JM07) and Broto Branco (JM03), which were collected in the municipality of Jangada (Figure 9).

JM07 (Sem Nome) stood out for the having the following characteristics: smallest leaf lobe width; longest leaf length and leaf lobe width-length ratio, lowest value for height of the first branch and lowest height compared to other ethno-varieties (Figure 10). The ethno-variety JM03 (Broto Branco) also had the lowest height, lowest height of the first branch, longest leaf length, but had the longest petiole length and the lowest number of roots per plant (Figure 11).

It is noteworthy that the varieties preferred by farmers are those with the highest height of the first branch, because it facilitates the maintenance and harvesting practices of the crop. Plants that branch too close to the ground make weeding difficult, one of the main activities performed during crop cultivation (Gomes, 2007). Therefore, the ethno-varieties JM03 and JM07 presented this undesirable characteristic by farmers.

The analysis of the relative contribution of the nine quantitative characters among the 45 cassava ethno-varieties allowed us to identify of the most important characteristics (Table 4). According to the analysis done by Singh (1981), the characteristics that most contributed to the differentiation of ethno-varieties were root length $(30.23 \%)$, petiole length $(20.82 \%)$, number of roots $(17.53 \%)$ and leaf length-width ratio $(13.78 \%)$. On the other hand, the descriptors that contributed the least were root diameter (7.01\%), leaf length 
(5.69\%), height of the first branch $(3.75 \%)$, leaf width $(0.74 \%)$ and height of the plant $(0.43 \%)$.

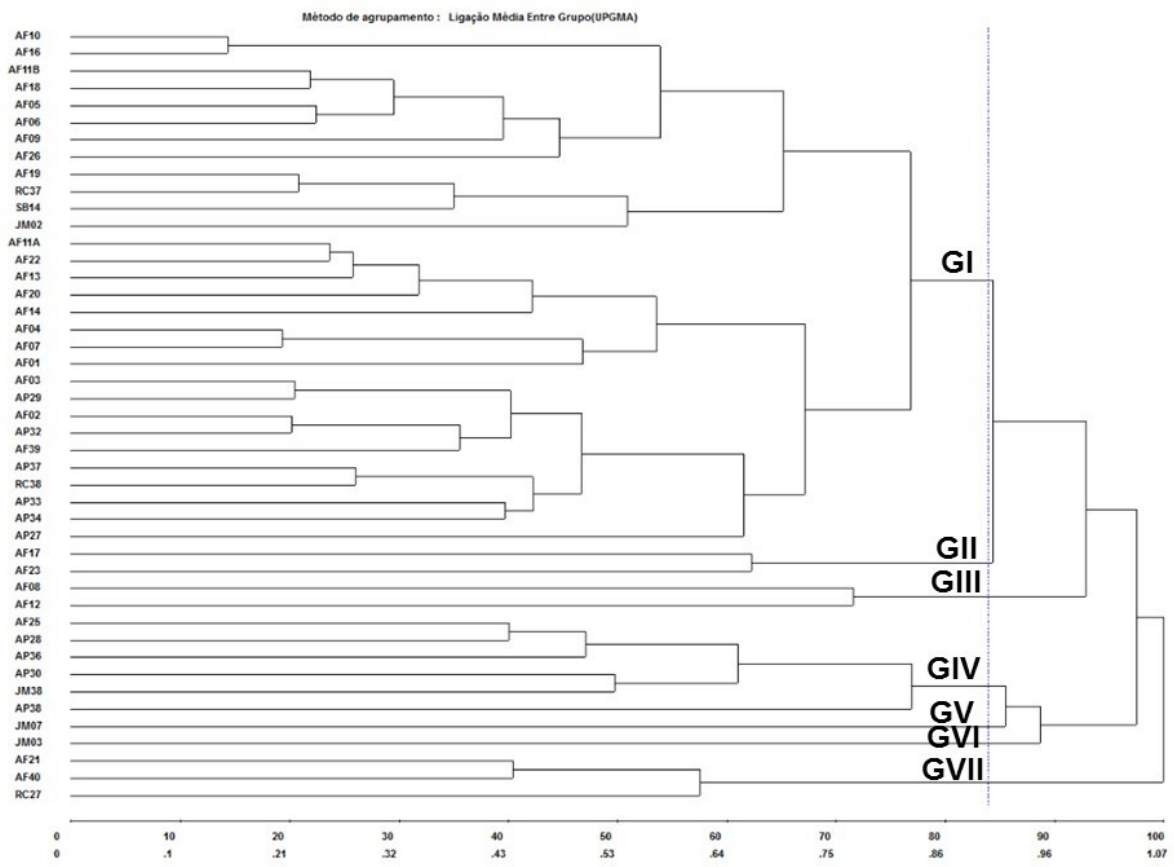

Figure 9. UPGMA Dendrogram obtained via nine quantitative characters based on Euclidean distance in 45 cassava ethno-varieties collected in the state of Mato Grosso. Performed using the GENES software (Cruz, 2013). Cophenetic correlation coefficient (CCC) 63.95\%.

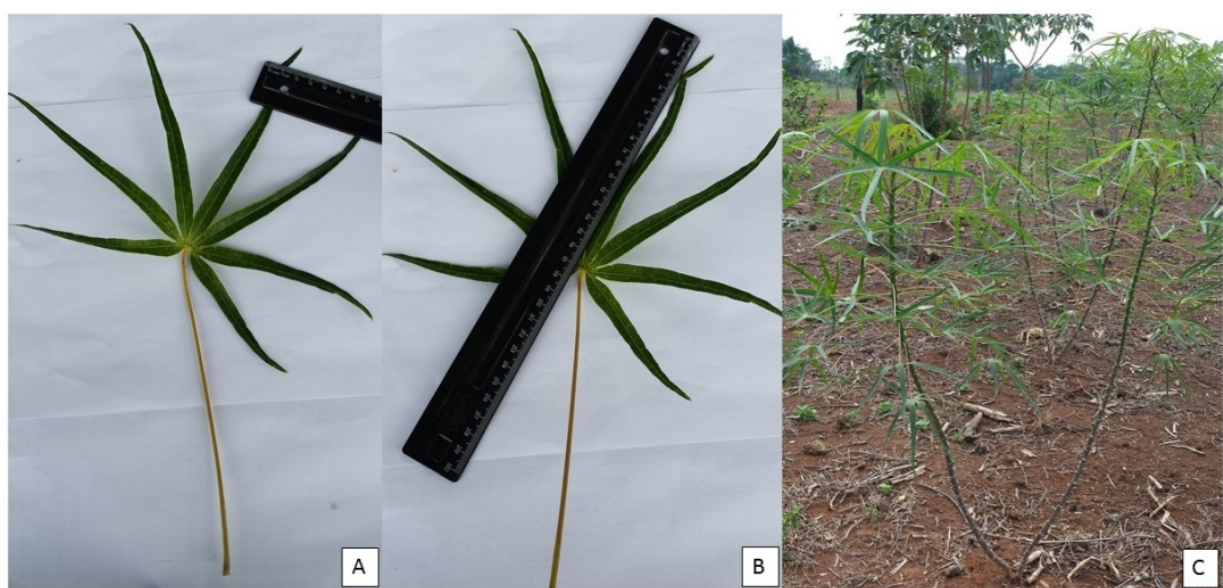

Figure 10. Quantitative characteristics that most contributed to the differentiation of the JM07 cassava ethnovariety identified by the farmer as Sem Nome. A) Leaf lobe width; B) Leaf length; C) Height of first branching level and height of plant. 


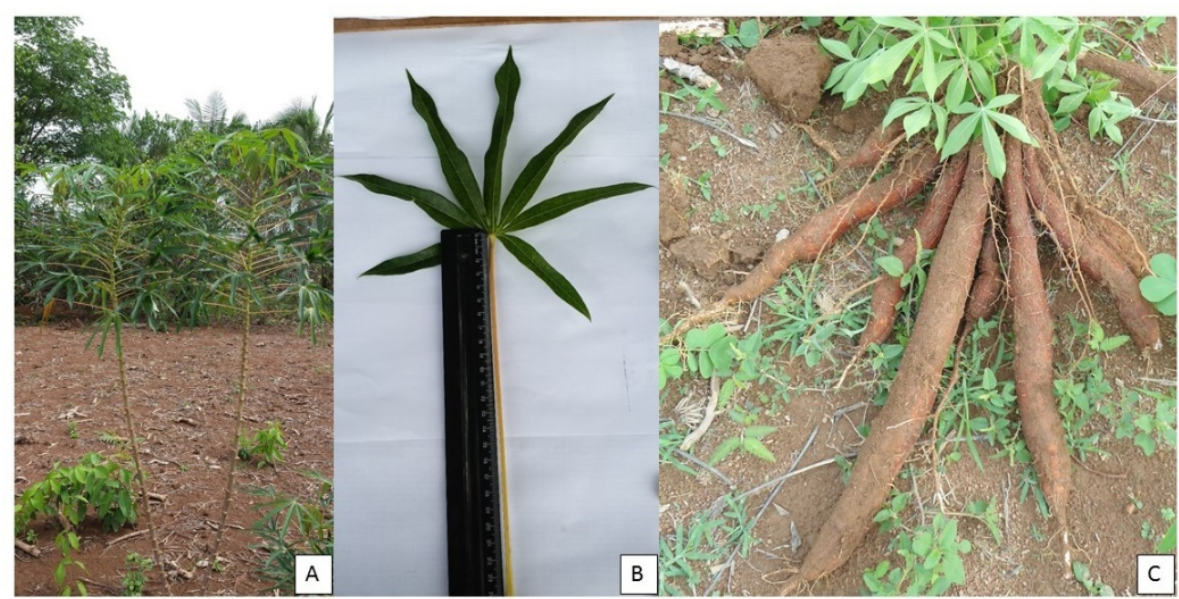

Figure 11. Quantitative characteristics that most contributed to the differentiation of cassava ethno-variety JM03 (Broto Branco). A) Height of plant; B) Height of first branching level; C) Number of roots per plant.

A similar result was found by Zuin et al. (2009) while evaluating the quantitative characteristics that most contributed to explaining the genetic divergence between 43 accessions of table cassava. The results indicated that the average length of tuberous roots $(32.04 \%)$, the average length of petioles $(18.04 \%)$ and the average number of tuberous roots per plant $(16.05 \%)$ were the characteristics that most contributed to the diversity. The characteristics for tuberous root diameter, average plant height and average height of the first branch were the ones that least explained the genetic divergence, contributing $0.27 \%$, $0.47 \%$ and $0.56 \%$, respectively, as is reported in our study.

Table 4. Relative contribution (\%) of the nine quantitative descriptors for genetic divergence in 45 cassava ethno-varieties, obtained by the Singh method (1981).

\begin{tabular}{ll}
\hline Characteristics & S.j (\%) \\
\hline Length of root & 30.23 \\
Length of petiole & 20.82 \\
Number of roots & 17.53 \\
Leaf lobe length-width ratio & 13.78 \\
Diameter of root & 7.01 \\
Length of leaf & 5.69 \\
Height of first branching level & 3.75 \\
Width of leaf & 0.74 \\
Height of plant & 0.43 \\
\hline
\end{tabular}

\section{Molecular characterization}

The 15 microsatellite loci used for 45 cassava ethno-varieties amplified a total of 109 alleles, ranging from two (SSRY126) to 12 alleles (SSRY28), and averaging 7.27 alleles per locus (Table 5).

Ortiz et al. (2016) used 13 SSR loci in the genetic characterization of cassava and found a total of 40 alleles with an average of 3.07 alleles per loci. Siqueira et al. (2010) evaluated 83 cassava accessions in Mato Grosso do Sul, based on 9 microsatellite loci, 
found 66 alleles, with an average of 6 alleles per loci. Mezette et al. (2013) studied the morphological and molecular diversity of cassava genotypes with 14 SSR loci and obtained an average of 3.53 alleles per locus, out of a total of 419 cassava accessions.

The number of alleles obtained in this study was higher than that reported by other authors. This fact can be explained by the different origins of the cassava ethno-varieties that were collected in five municipalities of different regions of the state of Mato Grosso. It can be observed that the selection process as practiced by the farmers favors the expansion and the maintenance of the cassava's genetic diversity, as also observed by Elias et al. (2001), Zuin et al. (2009), Costa et al. (2013).

Table 5. Genetic diversity among the 45 cassava ethno-varieties studied in 15 SSR loci. Number of alleles (n); expected heterozygosity $\left(H_{e}\right)$; observed heterozygosity $\left(H_{o}\right)$ and polymorphic information content (PIC).

\begin{tabular}{lrlll}
\hline Loci & $\mathbf{n}$ & $\boldsymbol{H}_{\boldsymbol{e}}$ & $\boldsymbol{H}_{\boldsymbol{o}}$ & PIC \\
\hline SSRY21 & 7 & 0.75 & 0.92 & 0.71 \\
SSRY28 & 12 & 0.76 & 0.94 & 0.74 \\
SSRY27 & 7 & 0.74 & 0.80 & 0.71 \\
SSRY35 & 5 & 0.54 & 0.69 & 0.47 \\
SSRY8 & 7 & 0.65 & 0.80 & 0.60 \\
GAGG5 & 3 & 0.52 & 0.67 & 0.41 \\
GA12 & 8 & 0.73 & 0.85 & 0.70 \\
GA21 & 4 & 0.64 & 0.80 & 0.75 \\
GA131 & 10 & 0.78 & 0.64 & 0.73 \\
SSRY43 & 10 & 0.76 & 0.51 & 0.63 \\
SSRY47 & 0.65 & 0.41 & 0.08 \\
SSRY126 & 11 & 0.09 & 0.00 & 0.63 \\
GA136 & 2 & 0.69 & 0.91 & 0.68 \\
GA140 & 6 & 0.72 & 0.69 & 0.79 \\
SSRY40 & 8 & 0.81 & 0.61 & 0.61 \\
\hline Median & 9 & 0.66 & 0.68 & \\
\hline
\end{tabular}

Table 5 presents estimates of genetic-statistical parameters of molecular analyses. It can be noted that the expected heterozygosity $\left(H_{e}\right)$ observed heterozygosity $\left(H_{o}\right)$ presented averages from 0.66 to 0.68 , respectively, with values ranging between 0.09 (SSRY126) and 0.81 (SSRY40) for $H_{e}$, and from 0.00 (SSRY126) to 0.94 (SSRY28) for $H_{o}$. As a general average, $H_{o}$ was greater than $H_{e}$ in 9 of the 15 loci evaluated (Table 5), which suggests excess heterozygotes in relation to the Hardy-Weinberg equilibrium model.

Similar results were found by de Pedri et al. (2019), who evaluated the genetic diversity of cassava ethno-varieties, with average values of 0.674 for $H_{e}$ and an average of 0.875 for $H_{o}$. All microsatellite loci analyzed showed higher observed heterozygosity in relation to expected heterozygosity, which indicates a predominance of heterozygotes in the set evaluated by the author. Turyagyenda et al. (2012), who studied genetic diversity among traditional cassava accesses cultivated by farmers in Uganda, also obtained values for the average expected heterozygosity of 0.667 , while the observed heterozygosity presented an average of $0.726, H_{o}$ being greater than $H_{e}$.

The polymorphic information content (PIC) for each marker presented values between 0.08 (SSRY126) and 0.79 (SSRY40), with an average of 0.61. PIC expresses the quality of the marker in genetic studies, therefore, loci with values above 0.50 were considered very informative (12 loci), and are indicated for future studies of the genetic 
diversity of cassava. According to the classification of Botstein et al. (1980), loci may be classified as moderately informative ( 0.25 to 0.50$)$ and minimally informative ( $\leq$ 0.25). Thus, in our study, two loci were considered moderately informative (GAGG5 and SSRY35) and one as minimally informative (SSRY126).

Figure 12, based on SSR markers, revealed the formation of four distinct groups using the UPGMA clustering method, with the first group (GI) allocating 91\% ethnovarieties, in this group, there were ethno-varieties of various origins. It is also possible to observe the duplicity of individuals AF25 and AF26 (Mandioca Batatinha and Pramuquem), both from the municipality of Alta Floresta. However, by analyzing the qualitative and quantitative characteristics, this duplicity was not noted among the samples, since they have distinct characteristics. Thus, the exclusion any of the ethnovarieties was not recommended when considering the evaluated data set.

The second group (GII) clustered $4 \%$ of the ethno-varieties, and was composed by the samples for Mandioca Manteiga (AP37) and Amarela de Minas (AP38), from the municipality of Apiacás. The third (GIII) and fourth (GIV) groups were composed of only one ethno-variety each, AF03 (Mandioca Cenoura) and AF40 (Paraguaia), respectively, and were from the municipality of Alta Floresta (Figure 13).

The divergence of AF40 ethno-variety (Paraguaia) was confirmed in the qualitative characteristics. However, it presented many root constrictions, which is an undesirable characteristic.

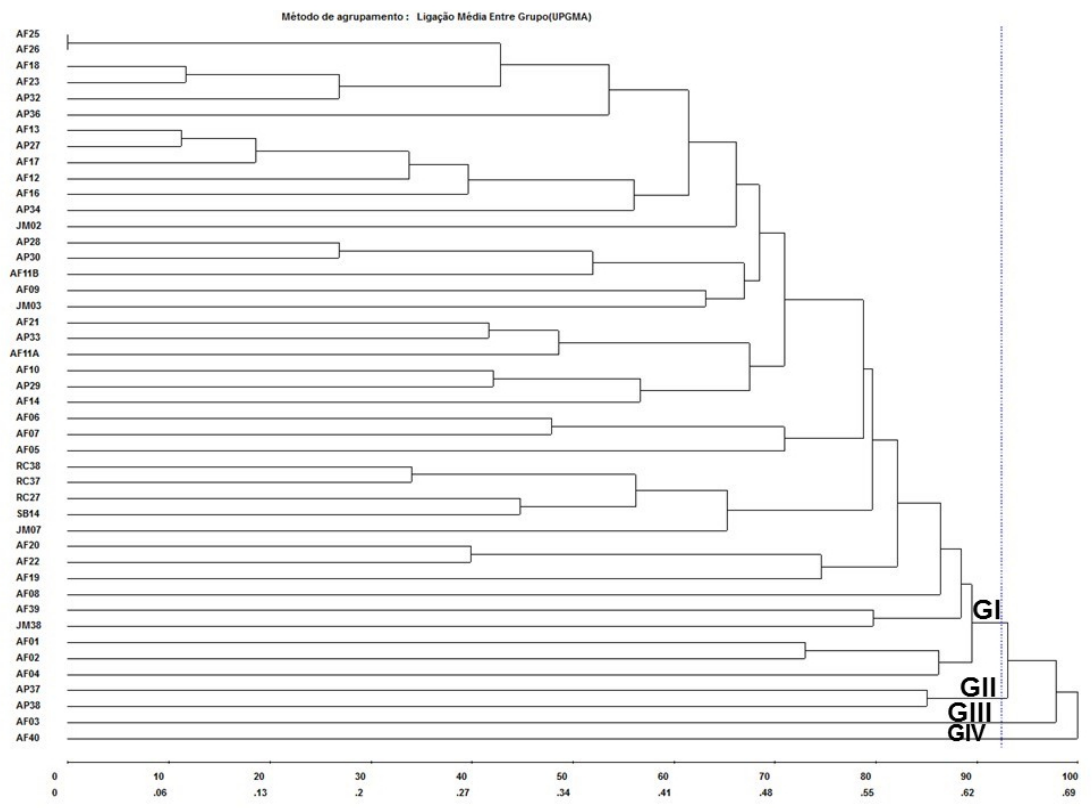

Figure 12. Dendrogram resulting from the cluster analysis of 45 cassava ethno-varieties obtained via the UPGMA method using the Jaccard dissimilarity coefficient with 15 SSR loci. Performed using the GENES software (CRUZ, 2013). Cophenetic correlation coefficient (CCC) $82.54 \%$. 


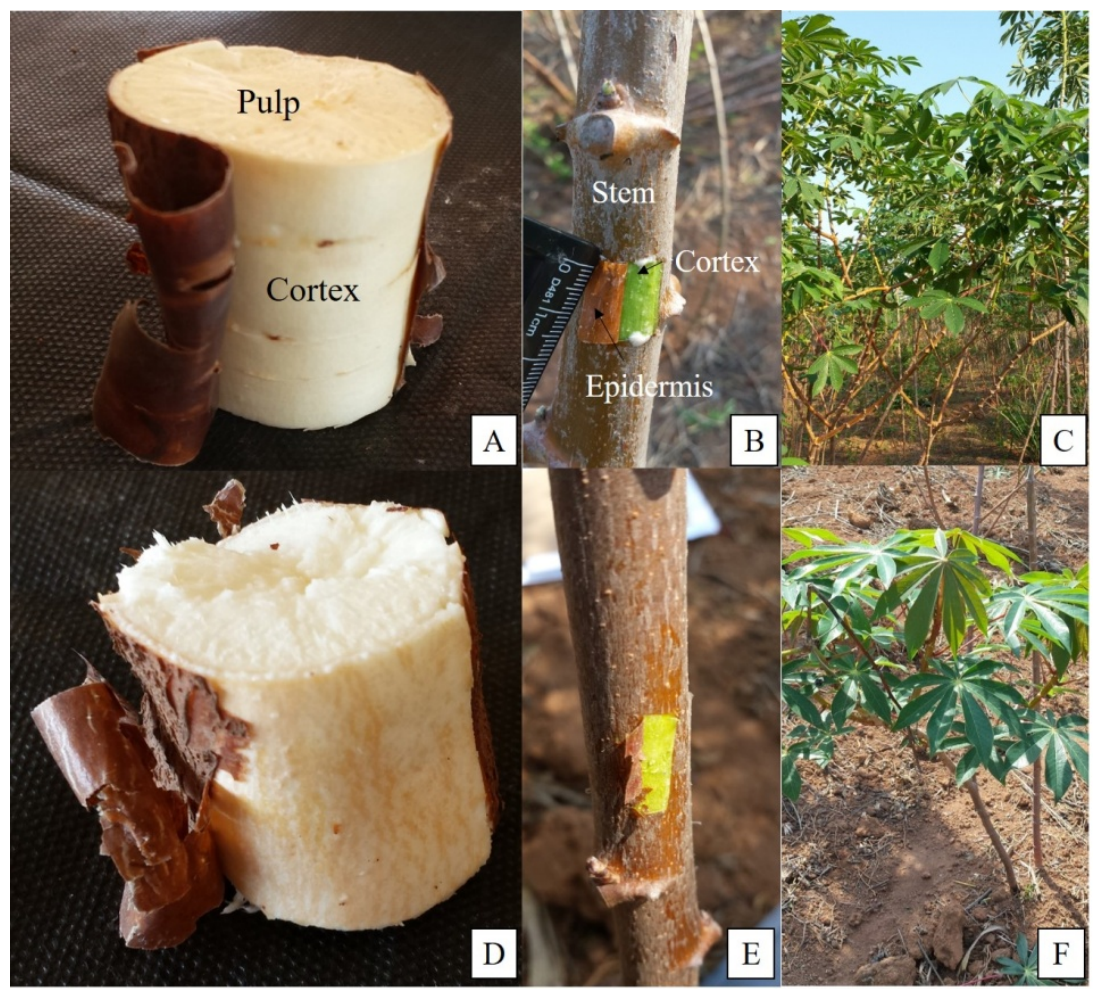

Figure 13. Phenotypic characteristics present in ethno-varieties AF03 and AF40. Characteristics of AF03 (Mandioca Cenoura): A) Root pulp color (yellow) and root cortex color (cream); B) stem epidermis color (light brown); external color of the stem (light brown); stem cortex color (dark green) and C) developed plant. Characteristics of AF40 (Paraguaia): D), Root pulp color (white); root cortex color (cream); F) external color of the stem (orange); stem epidermis color (light brown) and stem cortex color (light green) and G) developed plant.

\section{Genetic diversity based on joint data analysis}

In the joint analysis of quantitative, qualitative and molecular data by the UPGMA clustering method based on the Gower distance to the cut-off point at $82.04 \%$, the formation of five genetic groups was found (Figure 14). The GI group was formed by 15 ethnovarieties, 13 belonging to Alta Floresta and only two ethno-varieties from Apiacás (AP29 = Mandioca Liberata; AP27 = Mandioca de São Paulo). The GII group has the largest number of ethno-varieties (27), with a mixture of ethno-varieties of different origins. Groups GIII and GIV and GV presented isolated individuals (AF08: Branca Comum; AF40: Paraguaia and RC27: Osso), therefore being the most divergent groups.

The ethno-variety AF40 (Paraguaia) also remained isolated in this analysis, confirming what had already been found through the analysis of qualitative and molecular characteristics. The same was found for the ethno-varieties AF08 (Branca Comum) and RC27 (Osso) which were also allocated among the most dissimilar groups for quantitative descriptors and joint analysis. 


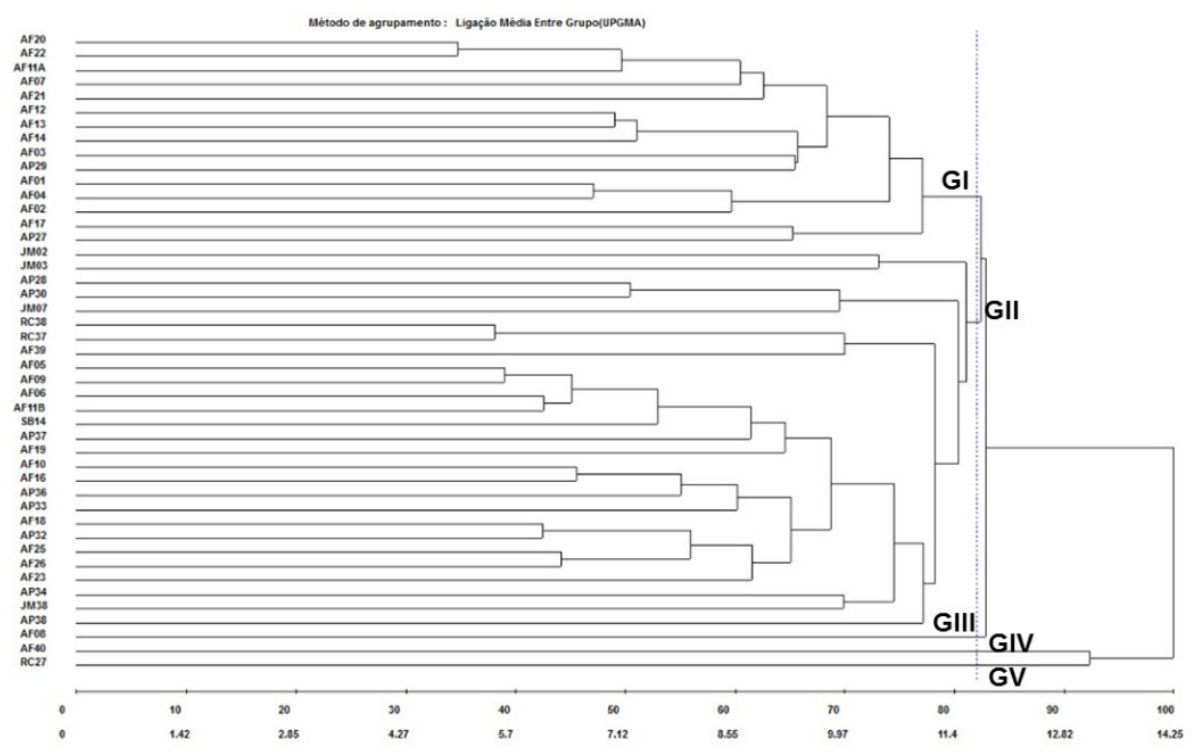

Figure 14. Dendrogram resulting from combined analysis of qualitative, quantitative and molecular data (SSR), based on the Gower distance (1971). Performed using the GENES software (CRUZ, 2013). Cophenetic correlation coefficient (CCC) $70.52 \%$.

The value of the cophenetic correlation coefficient (CCC) was satisfactory for all distance matrices, revealing it to be a good fit between the dissimilarity dendrogram and the original dissimilarity matrix (Table 6). This value is considered to be good when it is significant and equal to, or greater than, 0.7 (Rohlf, 1970), and in this study, only the matrix for quantitative data presented a lower value for cophenetic correlation.

Table 6. Values obtained for the cophenetic correlation coefficient between the matrices for genetic distance in relation to clustering using the UPGMA method.

\begin{tabular}{ll}
\hline Matrices & Cophenetic Correlation Coefficient \\
\hline Qualitative & $0.72^{* *}$ \\
Quantitative & $0.64^{* *}$ \\
Molecular & $0.82^{* *}$ \\
Joint & $0.70^{* *}$ \\
\hline$* *$ cophenetic correlation coefficient significant at $1 \%$ probability &
\end{tabular}

The results for the correlation between dissimilarity matrices revealed significance, but were of low magnitude. The qualitative and quantitative variables showed a correlation of $31 \%$, and between the qualitative and molecular data a correlation of $12.4 \%$, however there is no correlation between the quantitative and molecular variables, i.e., there is no correspondence between them (Table 7). 
Table 7. Correlations between matrices for genetic distance, estimated using qualitative, quantitative and molecular characteristic analyses (SSR) among 45 cassava ethno-varieties.

\begin{tabular}{llll}
\hline Matrices & Qualitative & Quantitative & Molecular \\
\hline Qualitative & - & $0.310^{++}$ & $0.124^{+}$ \\
Quantitative & & - & $0.032^{\mathrm{ns}}$ \\
Molecular & & - \\
\hline$(++)$ and (+): significant at 1 and 5\% probability; ns: insignificant, by Mantel test, based on 5.000 simulations.
\end{tabular}

This lack of association between the estimates should not be considered as a limitation of this tool to access genetic variability, but as an indication of their complementarity. This can also be explained by the different properties of molecular markers and quantitative and qualitative characteristics (Lefebvre et al., 2001; Vieira et al., 2013).

Thus, it is possible to establish a scenario in which the associations between genetic distances/dissimilarities estimated by qualitative, quantitative and molecular characters will be closer as the association between loci that control quantitative and qualitative characters and bands is greater. evaluated and the higher the number of quantitative and qualitative characters evaluated, which will increase the genome coverage of the accessions (Máric et al., 2004; Roy et al., 2004; Vieira et al., 2008a).

\section{CONCLUSIONS}

The collection of ethno-varieties presents different genetic divergence according to the variable, that is, if it is qualitative phenotypic, quantitative and molecular phenotypic.

For the choice of progenitors within a range of ethno-varieties, the combination of phenotypic and molecular analyses is complementary, but for characterization purposes aimed at conserving genetic resources, one type of characterization is sufficient.

The ethno-variety AF40 (Paraguaia) stands out for having the greatest divergence for qualitative, molecular characteristics, and in the joint analysis.

Among the ethno-varieties studied, the ethno-variety AF13 (Amarela I) presented the most favorable characteristics from a commercialization, consumption and agronomic point of view.

\section{ACKNOWLEDGMENTS}

This work was carried out with the support of the Coordination of Improvement of Higher Education Personnel - Brazil (CAPES) Financing Code 001.

\section{CONFLICTS OF INTEREST}

The authors declare no conflict of interest.

\section{REFERENCES}

Alvares CA, Stape JL, Sentelhas PC, Gonçalves JLM, et al. (2013). Koppen's climate classification map for Brazil. Meteorol. Z. 22: 711-728. 
Alves-Pereira A, Peroni N, Abreu AG, Gribel R, et al. (2011). Genetic structure of traditional varieties of bitter manioc in three soils in Central Amazonia. Genetica. 139: 1259-1271.

Avijala MF (2013). Diversidade e estimativas de parâmetros genéticos em mandioca (Manihot esculenta Crantz), oriunda de Moçambique. Master's thesis, Universidade Federal de Viçosa, Minas Gerais.

Barbosa CZR, Alves JMA, Schwengber DR and Smiderle OJ (2007). Características morfológicas e agronômicas de dez clones de mandioca cultivados no Estado de Roraima. Agro@mbiente On-line. 1: 28-31.

Borém A and Caixeta E (2016). Marcadores Moleculares. 1st edn. UFV, Viçosa.

Botstein D, White RL, Skolnick M and Davis RW (1980). Construction of a genetic linkage map in man using restriction fragment length polymorphisms. Am. J. Hum. Genet. 32: 314-331.

Carrasco NF, Oler JRL, Marchetti FF, Carniello MA, et al. (2016). Growing Cassava (Manihot esculenta) in Mato Grosso, Brazil: Genetic Diversity Conservation in Small-Scale Agriculture. Econ. Bot. 70: 15-28.

Chavarriaga-Aguirre PP, Maya MM, Bonierbale MW, Kresovich S, et al. (1998). Microsatellites in cassava (Manihot esculenta Crantz): discovery, inheritance and variability. Theor. Appl. Genet. 97: 493-501.

Costa TR, Vidigal Filho PS, Gonçalves-Vidigal MC, Galván MZ, et al. (2013). Genetic diversity and population structure of sweet cassava using simple sequence repeat (SSR) molecular markers. Afr. J. Biotechnol. 12: 10401048.

Cruz CD (2006). Programa Genes: Análise multivariada e simulação. 1st edn. UFV, Viçosa.

Cruz CD (2013). Genes - a software package for analysis in experimental statistics and quantitative genetics. Acta Sci. Agron. 35: 271-276.

Cruz CD and Regazzi AJ (2001). Modelos biométricos aplicados ao melhoramento genético. 2st edn. UFV, Viçosa.

Cruz CD, Ferreira MF and Pessoni LA (2011). Biometria aplicada ao estudo da diversidade genética. 1st edn. Suprema, Visconde do Rio Branco, Minas Gerais.

Doyle JJ and Doyle JL (1990). Isolation of plant DNA from fresh tissue. Focus. 12: 13-15.

Elias M, Penet L, Vindry P, Mckey D, et al. (2001). Unmanaged sexual reproduction and the dynamics of genetic diversity of a vegetatively propagated crop plant, cassava (Manihot esculenta Crantz), in a traditional farming system. Mol. Ecol. 10: 1895-1907.

EMBRAPA (Empresa Brasileira de Pesquisa Agropecuária) (2013). Sistema brasileiro de classificação de Solos. 3st edn. Embrapa, Brasília.

EMBRAPA (Empresa Brasileira de Pesquisa Agropecuária) (2014). 2a Oficina de Concertação Estadual de Mato Grosso. Available [https://www.embrapa.br/documents/1354377/2109296/Documento+base+CONTEXTUALIZA\%C3\%87\%C3\%83 O.pdf/247bf759-27f9-4b4e-afad-1aa6cabd18d4?version=1.0]. Accessed April 24, 2020.

EMBRAPA (Empresa Brasileira de Pesquisa Agropecuária) (2017). Mandioca em números. Available at [https://www.embrapa.br/congresso-de-mandioca-2018/mandioca-em-numeros]. Accessed April 24, 2020.

FAO (Organização das Nações Unidas para Agricultura e Alimentação) (2013). Save and Grow: Cassava. Available at [http://www.fao.org/3/a-i3278e.pdf]. Accessed April 15, 2020.

Faraldo MIF, Silva RM, Ando A and Martins PS (2000). Variabilidade genética de etnovariedades de mandioca em regiões geográficas do Brasil. Sci. Agric. 57: 499-505.

Ferreira ME and Grattapaglia D (1998). Introdução ao uso de marcadores moleculares em análise genética. 3st edn. Embrapa, Brasília.

Fukuda WMG and Guevara CL (1998). Descritores morfológicos e agronômicos para a caracterização de mandioca (Manihot esculenta Crantz). Embrapa, Mandioca e Fruticultura, Cruz das Almas. Available at [https://www.infoteca.cnptia.embrapa.br/infoteca/handle/doc/638631]. Accessed April 15, 2020.

Fukuda WMG, Oliveira RD, Fialho JDF, Cavalcanti J, et al. (2005). Germoplasma de mandioca (Manihot esculenta Crantz) no Brasil. Rev. Bras. Mandioca. 18: 7-12.

Genemarker SoftGenetics. Software PowerTools for Genetic Analysis. Available at [https://softgenetics.com/GeneMarker.php]. Accessed April 20, 2020

Gomes CN (2007). Caracterização morfo-agronômica e diversidade genética em mandioca Manihot esculenta Crantz. Master's thesis, Universidade Federal de Lavras, Minas Gerais.

Gower JC (1971). A general coefficient of similarity and some of its properties. Biometrics. 27: 857-874, 1971.

Iglesias C, Mayer J, Chavez L and Calle F (1997). Genetic potential and stability of carotene content in cassava roots. Euphytica. 94: 367-373.

Lefebvre V, Goffinet B, Chauvet JC, Caromel B, et al. (2001). Evaluation of genetic distances between pepper inbred lines for cultivar protection purposes: comparison of AFLP, RAPD, and phenotypic data. Theor. Appl. Genet. 102: 741-750.

Mantel N (1967). The detection of disease clustering and a generalized regression approach. Cancer Res. 27: 209-220.

Máric S, Bolaríc S, Martincic J, Pejíc I, et al. (2004). Genetic diversity of hexaploid wheat cultivars estimated by RAPD markers, morphological traits and coefficients of parentage. Plant Breeding 123:366-369. 
Mba REC, Stephenson P, Edwards K, Melzer S, et al. (2001). Simple sequence repeat (SSR) markers survey of the cassava (Manihot esculenta Crantz) genome: towards an SSR-based molecular genetic map of cassava. Theor. Appl. Genet. 102: 21-31.

Mezette TF, Blumer CG and Veasey EA (2013). Morphological and molecular diversity among cassava genotypes. Pesq. Agropec. Bras. 48: 510-518.

Mtunguja MK, Ranjan A, Laswai HS, Muzanila Y, at al. (2015). Genetic diversity of farmer-preferred cassava landraces in Tanzania based on morphological descriptors and single nucleotide polymorphisms. Plant Genet. Resour. 15: 138-146.

Nick C, Carvalho SPD, Madeira ASJ, Custódio TN, et al. (2010). Divergência genética entre subamostras de mandioca. Bragantia. 69: 289-298.

Ortiz AHT, Rocha VPC, Moiana LD, Gonçalves-Vidigal MC, et al. (2016). Population Structure and Genetic Diversity in Sweet Cassava Cultivars from Paraná, Brazil. Plant. Mol. Biol. Rep. 34: 1153-1166.

Pedri ECM, Hoogerheide ESS, Tiago AV, Cardoso ES, et al. (2019). Genetic diversity of cassava landraces cultivated in northern Mato Grosso State, Brazil, using microsatellite markers. Genet. Mol. Res. 18: gmr18315.

Rohlf FJ (1970). Adaptive hierarchical clustering schemes. Syst. Biol. 18: 58-82.

Roy JK, Lakshmikumaran MS, Balyan HS and Gupta PK (2004). AFLP-based genetic diversity and its comparison with diversity based on SSR, SAMPL, and phenotypic traits in bread wheat. Biochem. genet. 42: 43-59.

SEAB (Secretaria de Estado da Agricultura e do Abastecimento) (2017). Prognóstico mandioca 2017/18. Available at: [http://www.agricultura.pr.gov.br/arquivos/File/deral/Prognosticos/2018/Mandioca_2017_18.pdf]. Accessed April $24,2020$.

Silva RM, Faraldo MFI, Ando A and Veasey EA (2002). Variabilidade genética de etnovariedades de mandioca. In: Cultura de tuberosas amiláceas Latino Americanas (Cereda MP, eds). Fundação Cargil, São Paulo.

Singh D (1981). The relative importance of characters affecting genetic divergence. Indian J. Genet. Pl. Br. 41: 237-245.

Siqueira MVBM (2008). Diversidade genética de etnovariedades de mandioca (Manihot esculenta Crantz) em áreas de Cerrado no Estado de Mato Grosso do Sul e de variedades comerciais por meio de marcadores microssatélites. Master's thesis, Universidade de São Paulo, Escola Superior de Agricultura "Luiz de Queiroz" Centro de Energia Nuclear na Agricultura, Piracicaba.

Siqueira MVBM, Pinheiro TT, Borges A, Valle TL, et al. (2010). Microsatellite polymorphisms in cassava landraces from the Cerrado biome, Mato Grosso do Sul, Brazil. Biochem. genet. 48: 879-895.

Sokal RR and Rohlf FJ (1962). The comparison of dendrograms by objective methods. Taxon. 11: 33-40.

Souza E, Silva M and Silva S (2012). A cadeia produtiva da mandiocultura no vale do Jequitinhonha (MG): Uma análise dos aspectos sócio produtivos, culturais e da geração de renda para a Agricultura familiar. Isegoria. 1: 73-85.

Tiago AV, Hoogerheide ESS, Pedri ECM, Rossi FS, et al. (2019). Genetic diversity and population structure of cassava ethno-varieties grown in six municipalities in the state of Mato Grosso, Brazil. Genet. Mol. Res. 18: gmr18357.

Turyagyenda LF, Kizito EB, Ferguson ME, Baguma Y, et al. (2012). Genetic diversity among farmer-preferred cassava landraces in uganda. Afr. Crop Sci. J. 20: 15-30.

Vieira EA, Fialho JF, Faleiro GF, Bellon G, et al. (2013). Caracterização fenotípica e molecular de acessos de mandioca de indústria com potencial de adaptação às condições do cerrado do Brasil Central. Semin. Ciênc. Agrár. 34: 567582.

Vieira EA, Freitas Fialho J, Faleiro FG, Bellon G, et al. (2008a). Divergência genética entre acessos açucarados e não açucarados de mandioca. Pesq. Agropec. Bras. 43: 1707-1715.

Vieira EA, Fialho JF, Silva MS, Fukuda WMG, et al. (2008b). Variabilidade genética do banco de germoplasma de mandioca da Embrapa Cerrados acessada por meio de descritores morfológicos. Científica. 36: 56-67.

Zago BW, Barelli MAA, Hoogerheide ESS, Correia CL, et al. (2017). Morphological diversity of cassava accessions of the south-central mesoregion of the State of Mato Grosso, Brazil. Genet. Mol. Res. 16: gmr16039725.

Zuin GC, Vidigal Filho S, Kvitschal VM, Gonçalves-Vidigal MC, et al. (2009). Divergência genética entre acessos de mandioca-de-mesa coletados no município de Cianorte, região Noroeste do Estado do Paraná. Semin. Ciênc. Agrár. 30: 21-30. 